Check for updates

Cite this: RSC Adv., 2019, 9, 1536

Received 6th December 2018

Accepted 19th December 2018

DOI: $10.1039 / c 8 r a 10040 c$

rsc.li/rsc-advances

\title{
Solvent- and transition metal-free amide synthesis from phenyl esters and aryl amines $\dagger$
}

\author{
Sergey A. Rzhevskiy, (D) ab Alexandra A. Ageshina, (D) a Gleb A. Chesnokov, (D) ab \\ Pavel S. Gribanov, (ID ac Maxim A. Topchiy, (D) ab Mikhail S. Nechaev (D)*ab \\ and Andrey F. Asachenko (D)*ab
}

A general, economical, and environmentally friendly method of amide synthesis from phenyl esters and aryl amines was developed. This new method has significant advantages compared to previously reported palladium-catalyzed approaches. The reaction is performed transition metal- and solvent-free, using a cheap and environmentally benign base, $\mathrm{NaH}$. This approach enabled us to obtain target amides in high yields with high atom economy.

\section{Introduction}

Amides are one of the widest classes of compounds found in natural products, as well as in pharmaceuticals. Their synthesis has been, and continues to be, the focus of significant attention in synthetic chemistry. ${ }^{1-3}$ Many of the well-established methods for amide synthesis involve reagents that are difficult to handle and lead to generation of large quantities of waste products. Recent publications demonstrated the increasing interest of the pharmaceutical industry (e.g. ACS Green Chemistry Institute Pharmaceutical Roundtable) in amide bond formation. Thus, amide bond formation is among the most important synthetic transformations requiring improved methods. ${ }^{4}$

Most popular approaches of amide synthesis utilize preliminary preparation of expensive activated esters or use of stoichiometric quantities of peptide-coupling reagents, followed by treatment with amines. ${ }^{2,5,6}$ Several methods of one-pot direct synthesis of amides from carboxylic acids as well as a number of non-conventional approaches, such as oxidative amidation of alcohols, are reported. ${ }^{3,4,-9}$ Transamidation route to amides is also well-known., ${ }^{40-15} \mathrm{~A}$ number of reviews were published on the methods of amide synthesis., ${ }^{916-19}$

Amide synthesis from amines and cheap unactivated esters using various catalysts is rather promising. ${ }^{20-26}$ Recent publications have documented rapid transformation of BuchwaldHartwig cross-coupling into an efficient tool to create $\mathrm{C}-\mathrm{N}$ bonds

${ }^{a}$ A.V. Topchiev Institute of Petrochemical Synthesis, Russian Academy of Sciences, Leninsky Prospect 29, Moscow, 119991, Russia. E-mail: aasachenko@ips.ac.ru

${ }^{b}$ M.V. Lomonosov Moscow State University, Leninskie Gory 1 (3), Moscow, 119991, Russia.E-mail:m.s.nechaev@org.chem.msu.ru

'A.N. Nesmeyanov Institute of Organoelement Compounds, Russian Academy of Sciences, Vavilov str. 28, Moscow, 119991, Russian Federation

$\dagger$ Electronic supplementary information (ESI) available: Detailed experimental procedures, ${ }^{1} \mathrm{H}$ and ${ }^{13} \mathrm{C}$ NMR spectra. See DOI: $10.1039 / \mathrm{c} 8 \mathrm{ra10040c}$ from aryl halides and amines used abundantly in industrial fine organic synthesis. ${ }^{27-31}$

In the past two years, efforts of groups lead by Stephen G. Newman (Scheme 1A), ${ }^{32}$ Michal Szostak (Scheme 1B), ${ }^{33}$ and Nilay Hazari (Scheme 1C) ${ }^{34}$ resulted in a successful transfer of aryl halide cross-coupling techniques onto esters. ${ }^{35-37}$ Chemoselective cleavage of the $\mathrm{C}(\mathrm{acyl})-\mathrm{O}$ bond provided easy access to various arylamides hardly available by traditional methods. ${ }^{19,38-40}$ These new cross-coupling methods utilize easily available unactivated esters, non-nucleophilic amines, and air-stable catalytic systems. Despite the fact that the above-mentioned methods are rather efficient, they are not free from drawbacks, requiring toxic solvents, transition

Previous work:

A. IPrPd-catalyzed approach to amide bond formation: ${ }^{32}$

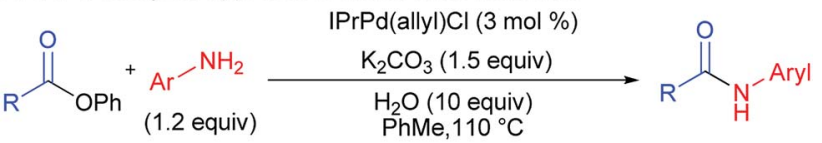

B. PEPPSI-IPr-catalyzed approach to amide bond formation: ${ }^{33}$

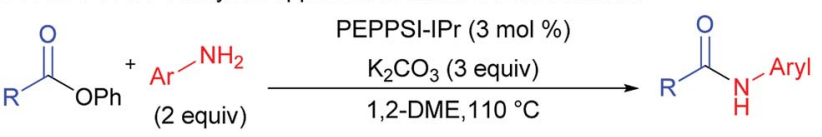

C. $\operatorname{SIPrPd}\left(t-B u\right.$-indenyl)CI for Buchwald-Hartwig coupling of aryl esters ${ }^{34}$

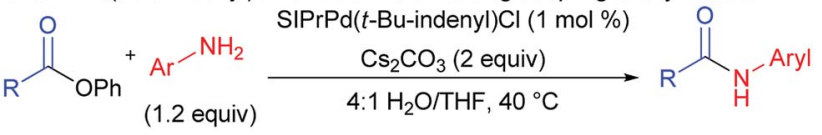

This work:

D. Solvent and transition metal-free amide bond formation from esters:

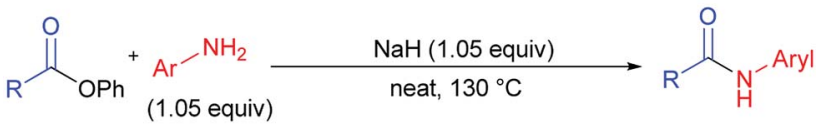

Scheme 1 Cross-coupling reactions of amines and esters 
metal-based catalysts, and generating a lot of waste (low atom economy).

One of the major challenges in organic chemistry is the development of methods that are of high performance, ecologically benign, and economically feasible. Application of solvents as reaction media negatively affects product cost through solvent price and cost of solvent processing or utilization. Besides, usage of solvents can cause harm for employees and environment. Therefore, development of cross-coupling reaction conditions requiring no use of solvents is rather promising since it could lower direct and indirect expenses by means of lower amount of waste, increase of reaction rate, lower catalyst load, and better synthesis scaling up.

For the last several years our group was active in the development of "green" chemical approaches that might be relevant both for academia and industry. Our target is "to eliminate organic solvents from organic chemistry" by development of solvent-free synthetic approaches. This motivated us to report for the first time a new general method of amides synthesis from phenyl esters under green solvent- and transition metal-free conditions. The implementation of this approach promises simplicity, high efficiency, atom economy and ecological safety, while giving opportunities to avoid particular disadvantages of conventional methods (Scheme 1D vs. Scheme 1A-C).

\section{Results and discussion}

We performed optimization of solvent-free amidation of phenyl esters using model reaction of $o$-toluidine and phenyl

Table 1 Optimization of the reaction conditions ${ }^{a}$

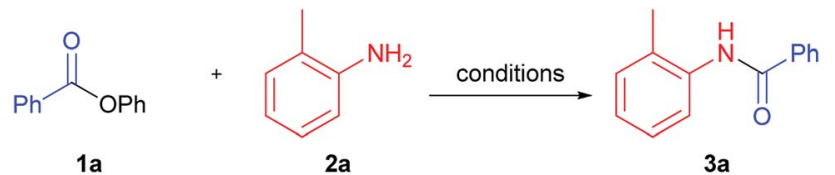

\begin{tabular}{lllll}
\hline Entry & Catalyst & Base & $T\left({ }^{\circ} \mathrm{C}\right)$ & $\mathrm{Yield}^{b}, \%$ \\
\hline 1 & 3 mol\% IPrPd(allyl)Cl & $\mathrm{K}_{2} \mathrm{CO}_{3}{ }^{c, d}$ & 110 & 98 \\
2 & 3 mol\% IPrPd(allyl)Cl & $\mathrm{K}_{2} \mathrm{CO}_{3}{ }^{c}$ & 110 & 90 \\
3 & - & $\mathrm{K}_{2} \mathrm{CO}_{3}$ & 110 & $32(3)^{e}$ \\
4 & - & $\mathrm{K}_{2} \mathrm{CO}_{3}$ & 150 & $39(32)^{e}$ \\
5 & - & $\mathrm{K}_{3} \mathrm{PO}_{4}$ & 150 & 57 \\
6 & - & $\mathrm{Cs}_{2} \mathrm{CO}_{3}$ & 150 & 15 \\
7 & - & $t$-BuOK & 150 & 38 \\
8 & - & $\mathrm{DBU}$ & 150 & 75 \\
9 & - & $\mathrm{DBN}$ & 150 & 56 \\
10 & - & $\mathrm{DABCO}$ & 150 & 61 \\
11 & - & $\mathrm{NaH}$ & 150 & 80 \\
12 & - & $\mathrm{NaH}$ & 130 & $97^{a}$ \\
13 & - & $\mathrm{NaH}$ & 120 & 95 \\
14 & - & $\mathrm{NaH}$ & 90 & 80
\end{tabular}

${ }^{a}$ Reaction conditions: phenyl benzoate $1 \mathrm{a}(0.7 \mathrm{mmol}), o$-toluidine $2 \mathrm{a}$ ( $0.735 \mathrm{mmol}, 1.05$ equiv.), base ( $0.735 \mathrm{mmol}, 1.05$ equiv.), $T{ }^{\circ} \mathrm{C}$ (oilbath temperature), $20 \mathrm{~h}$, heat. ${ }^{b}$ Yield determined by ${ }^{1} \mathrm{H}$ NMR of the crude mixture with BHT as internal standard. ${ }^{c} 1.5$ equiv. of base.

${ }^{d}$ Conditions ref. $32 .{ }^{e}$ Without base. benzoate (Table 1). Initially, we compared performance of $\operatorname{IPrPd}($ allyl)Cl, proposed by Stephen G. Newman, under solvent (Table 1, example 1), ${ }^{32}$ and solvent-free conditions (Table 1, example 2). Yield of product under solvent-free conditions was found to decrease from 98 to $90 \%$. Performing reaction in the absence of both solvent and catalyst resulted in product yield of $32 \%$ (Table 1, example 3). In the absence of the catalyst, solvent, and base the reaction proceeded with only $3 \%$ yield (Table 1, example 3). Temperature increase up to $150{ }^{\circ} \mathrm{C}$ in the absence of base and catalyst have led to a considerable increase of amide yield from 3 to $32 \%$ (Table 1, example 4). Utilization of $\mathrm{K}_{2} \mathrm{CO}_{3}$ base under these conditions resulted in a small increase of the product yield compared to base-free conditions, from 32 to $39 \%$ (Table 1, example 4). Since further increase of temperature seemed unreasonable, we screened bases available at $150{ }^{\circ} \mathrm{C}$. Replacement of $\mathrm{K}_{2} \mathrm{CO}_{3}$ with $\mathrm{Cs}_{2} \mathrm{CO}_{3}$, decreased the yield down to $15 \%$ (Table 1, example 6). Utilization of a strong base $t$-BuOK did not lead to increase of the reaction yield (Table 1, example 7). Reaction proceeded with higher yield (57\%) in case of $\mathrm{K}_{3} \mathrm{PO}_{4}$ (Table 1, example 5). Strong organic bases, such as DBN (1,5-diazabicyclo(4.3.0) non-5-ene $)^{41}$ and DABCO (1,4-diazabicyclo[2.2.2]octane) showed moderate yields, whereas DBU (1,8-diazabicyclo[5.4.0] undec-7-ene) ${ }^{17,18,23}$ was slightly more active (Table 1 , examples $8-10)$. The highest yield (80\%) was obtained when $\mathrm{NaH}$ was used as a base (Table 1, example 11).

Next, we studied the temperature effect on the product yield employing $\mathrm{NaH}$ as the most suitable base (Table 1, examples 11-14). It turned out that practically quantitative yield was achieved at $130{ }^{\circ} \mathrm{C}$ (Table 1 , example 12). Thus, heating of nearly equimolar mixture of phenyl benzoate, ortho-toluidine and sodium hydride in absence of solvent and palladium catalyst produced target amide 3a in almost quantitative yield.

With optimal conditions in hand, the scope and limitations of the elaborated conditions was examined; we screened various aryl amines in reaction with phenyl benzoate (Table 2). For example, aniline yielded $82 \%$ of corresponding amide (Table 2 , 3d). The described conditions were found to tolerate halogensubstituted anilines. In case of meta- and para-substituted F-, $\mathrm{Cl}$-, and Br-substituted anilines, as well as 2-fluoroaniline, amides were obtained in good to quantitative yields (Table $2, \mathbf{3} \mathbf{j}$, $3 \mathbf{k}, 3 \mathbf{l}, 3 \mathbf{v}, 3 \mathbf{w}, 3 \mathbf{u})$.

Anilines bearing one substituent at the ortho-position afforded products $\mathbf{3 a}, \mathbf{3 g}, \mathbf{3 p}$, $\mathbf{3} \mathbf{u}$ in high yields. Good yields were obtained for anilines with both donor (Table 2, 3h, 3i , 3o, 3p) and acceptor functional groups (Table 2, 3c, 3t). Utilization of acceptor heterocyclic amines resulted in some decrease in yields (Table 2, 3q, 3r, 3s). Notably, benzylamine also gave good product yield (Table 2, 3n).

Diminished yields were observed in case of anilines bearing bulky substituents in ortho-positions, e.g. anilines $2 \mathrm{e}$ and $2 \mathrm{f}$ (38\% for $3 \mathbf{e}, 62 \%$ for $3 \mathrm{f}$ ).

Next stage of our studies was screening of aryl esters in a model reaction with aniline (Table 3).

For example, esters of aliphatic acids demonstrated lower reactivity compared to phenyl benzoate (Table 3, examples 3df, 3di $v$ s. 3a of Table 2). The aniline reaction with heterocyclic 
Table 2 Scope of anilides ${ }^{a, b}$

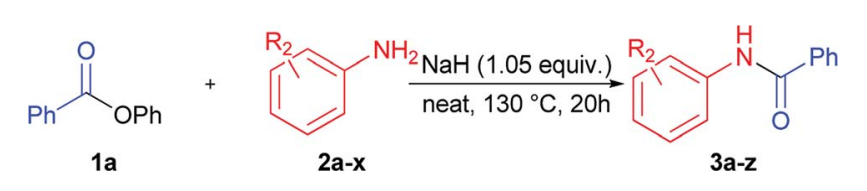<smiles>Cc1ccccc1NC(=O)c1ccccc1</smiles>

3a, $97 \%$

3d, $82 \%$<smiles>Cc1ccc(NC(=O)c2ccccc2)c(C)c1</smiles>

3g, $83 \%$<smiles>O=C(Nc1cccc(Cl)c1)Nc1cccc(C(=O)Nc2ccc(Cl)cc2)c1</smiles>

3j, $96 \%$<smiles>O=C(Nc1ccccc1Br)c1ccccc1</smiles>

3k, $84 \%$<smiles>O=C(NCc1ccccc1)c1ccccc1</smiles><smiles>O=C(Nc1ccc(O)cc1)c1ccccc1</smiles><smiles>O=C(Nc1ccccc1O)c1ccccc1</smiles><smiles>O=C(Nc1ccncc1)c1ccccc1</smiles>

3p, $80 \%$<smiles>O=C(Nc1ncccn1)c1ccccc1</smiles>

3q, $72 \%$<smiles>O=C(Nc1cccc(C(F)(F)F)c1)c1ccccc1</smiles>

3s, $61 \%$

3t. $84 \%$<smiles>O=C(Nc1ccc(F)cc1)c1ccccc1</smiles><smiles>O=C(Nc1cc(F)cc(F)c1)c1ccccc1</smiles>

3w, $77 \%$<smiles>O=C(Nc1ccc(Br)cc1)c1ccccc1</smiles>

3l, $>99 \%$<smiles>O=C(Nc1ccccn1)c1ccccc1</smiles><smiles>O=C(Nc1ccccc1F)c1ccccc1</smiles>

$3 u, 87 \%$<smiles>Cc1cc(C)cc(NC(=O)c2ccccc2)c1</smiles>

$3 \mathbf{x}, 76 \%$<smiles>O=C(Nc1ccccc1)c1ccccc1</smiles><smiles>O=C(Nc1ccc([N+](=O)[O-])cc1)c1ccccc1</smiles>

3c, $85 \%$

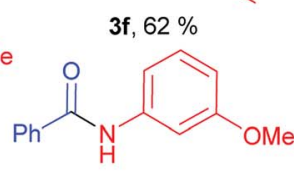

$3 \mathbf{i},>99 \%$<smiles>O=C(Nc1cccc2ccccc12)c1ccccc1</smiles>

$3 y, 72 \%$<smiles>O=C(Nc1ccc2ccccc2c1)c1ccccc1</smiles>

$3 \mathbf{z}, 96 \%$

${ }^{a}$ Reaction conditions: phenyl benzoate $1 \mathrm{a}(0.7 \mathrm{mmol})$, amine $2(0.735$ $\mathrm{mmol}$ ), $\mathrm{NaH}(0.735 \mathrm{mmol}), 130{ }^{\circ} \mathrm{C}$ (oil-bath temperature), 20 h. ${ }^{b}$ Yield determined by ${ }^{1} \mathrm{H}$ NMR of the crude mixture with BHT as internal standard.

acids esters proceeded with good yields (Table 3, examples 3dc, 3dh, 3dj).

Interestingly, five-membered heterocyclic esters exhibited higher activity than six-membered counterparts (Table 3, 3dh, 3dj vs. 3dc). The phenyl esters of para-substituted benzoic acids produced amides in high yields (3db, 3de, Table 3 vs. 3d, Table 2). Phenyl ester of sterically hindered 2,4,6-trimethylbenzoic acid showed lower reactivity (Table 3, 3dd).

Thus, we successfully elaborated conditions for high-yield solvent- and transition metal based catalyst-free amide synthesis and tested them on a wide range of substrates.

It should be noted that our method showed product yields comparable to those in palladium-catalyzed methods of amide synthesis (Table 4). In some cases, proposed method showed higher efficiency compared to palladium-catalyzed methods (Table 4, examples 3b, 3o, 3z, 3dh, 3v, 3c).

Thus, compared with previously reported transition-metalcatalyzed methods, the elaborated method possesses several advantages, the most important of which is exploitation of sodium hydride, one of the simplest and most readily available inorganic bases, whereas catalytic methods require expensive catalysts, bases and solvents. Absence of transition metals, solvents, toxic reagents for carboxylic group activation (e.g. carbodiimides) makes proposed protocol a viable alternative for green amide synthesis. At the same time several disadvantages, such as hydrogen evolution and high reaction temperature,

Table 3 Scope of phenyl esters ${ }^{a, b}$

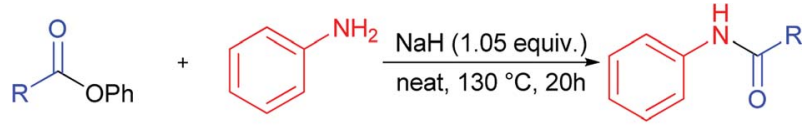

$1 b-$

2d

3db-dj<smiles>Cc1ccc(C(=O)Nc2ccccc2)cc1</smiles>

$3 \mathrm{db}, 81 \%$<smiles>O=C(Nc1ccccc1)c1ccc(Br)cc1</smiles>

3de, $81 \%$<smiles>O=C(Nc1ccccc1)c1ccco1</smiles>

3dh, $90 \%$
$3 d c, 86 \%$<smiles>CC(C)(C)CC(=O)Nc1ccccc1</smiles>

3df, $70 \%$<smiles>O=C(Cc1ccccc1)Nc1ccccc1</smiles>

3 di, $67 \%$<smiles>Cc1cc(C)c(C(=O)Nc2ccccc2)c(C)c1</smiles>

3dd, $42 \%$<smiles>O=C(Nc1ccccc1)c1cccc2ccccc12</smiles>

$3 \mathrm{dg}, 80 \%$<smiles>O=C(Nc1ccccc1)c1cccs1</smiles>

3dj, $84 \%$
${ }^{a}$ Reaction conditions: aryl ester $\mathbf{1}(0.7 \mathrm{mmol})$, aniline $\mathbf{2 d}(0.735 \mathrm{mmol})$, $\mathrm{NaH}(0.735 \mathrm{mmol}), 130{ }^{\circ} \mathrm{C}$ (oil-bath temperature), $20 \mathrm{~h} .{ }^{b}$ Yield determined by ${ }^{1} \mathrm{H}$ NMR of the crude mixture with BHT as internal standard. 
Table 4 Comparison of different methods

\begin{tabular}{|c|c|c|c|c|c|}
\hline Entry & Product & Method A ${ }^{a}, \%$ & Method $\mathrm{B}^{b}, \%$ & Method $C^{c}, \%$ & This work $^{d}, \%$ \\
\hline 1 & $3 a$ & 98 & 75 & 96 & 97 \\
\hline 2 & $3 \mathbf{b}$ & - & - & 92 & 95 \\
\hline 4 & $3 d$ & 91 & 96 & 90 & 82 \\
\hline 5 & $3 e$ & - & 90 & - & 38 \\
\hline 6 & $3 \mathbf{h}$ & - & 84 & 95 & 85 \\
\hline 9 & $3 q$ & 85 & - & - & 72 \\
\hline 10 & $3 \mathbf{v}$ & - & - & 95 & 99 \\
\hline 11 & $3 y$ & - & - & 87 & 72 \\
\hline 12 & $3 \mathrm{z}$ & - & - & 82 & 96 \\
\hline 13 & 3dh & 68 & 75 & - & 90 \\
\hline 14 & $3 d f$ & - & 78 & - & 70 \\
\hline
\end{tabular}

${ }^{a}$ Reaction conditions: $1(0.2 \mathrm{mmol}), 2(0.24 \mathrm{mmol}), \mathrm{IPrPd}($ allyl $) \mathrm{Cl}(0.006 \mathrm{mmol}), \mathrm{K}_{2} \mathrm{CO}_{3}(0.3 \mathrm{mmol}), \mathrm{H}_{2} \mathrm{O}(2 \mathrm{mmol})$, toluene $(1 \mathrm{~mL})$ at $110{ }^{\circ} \mathrm{C}$ for $16 \mathrm{~h}$ under Ar. ${ }^{b}$ Reaction conditions: 1 (1.0 equiv.), 2 (2.0 equiv.), $\mathrm{K}_{2} \mathrm{CO}_{3}$ (3.0 equiv.), PEPPSI-IPr $(3 \mathrm{~mol} \%), 1,2$-DME $(0.25 \mathrm{M}), 110{ }^{\circ} \mathrm{C}, 16 \mathrm{~h} .{ }^{c}$ Reaction conditions: $1(0.50 \mathrm{mmol}), 2(0.60 \mathrm{mmol}), \mathrm{Cs}_{2} \mathrm{CO}_{3}(0.75 \mathrm{mmol}), \operatorname{SIPrPd}\left(\eta^{3}-1-t-\mathrm{Bu}\right.$-indenyl $) \mathrm{Cl}(0.005 \mathrm{mmol}), \mathrm{H}_{2} \mathrm{O}(2 \mathrm{~mL}), \mathrm{THF}(0.5 \mathrm{~mL}), 40{ }^{\circ} \mathrm{C}, 4 \mathrm{~h}$. ${ }^{d}$ Reaction conditions: $1(0.7 \mathrm{mmol}), 2(0.735 \mathrm{mmol}), \mathrm{NaH}(0.735 \mathrm{mmol}), 130{ }^{\circ} \mathrm{C}$ (oil-bath temperature), $20 \mathrm{~h}$.

should be noted. Therefore, our method is a preparatively useful extension of existing methodology of amide synthesis.

\section{Conclusions}

A general, efficient, green method of aromatic amides synthesis from phenyl esters and aromatic amines under solvent- and transition metal-free conditions using equivalent amounts of $\mathrm{NaH}$ as a base was elaborated. Reaction and isolation procedures are simple, robust, easily reproducible, and scalable. The new method is characterized by high atom economy.

\section{Conflicts of interest}

There are no conflicts to declare.

\section{Acknowledgements}

S. A. Rzhevskiy, G. A. Chesnokov, P. S. Gribanov, M. A. Topchiy, M. S. Nechaev and A. F. Asachenko are thankful to Russian Science Foundation (RSF) for financial support (project number 17-13-01076). Authors are grateful to the Moscow State University (Russia) for the opportunity to use the NMR facilities of the Center for Magnetic Tomography and Spectroscopy. Part of this work was carried out by A. A. Ageshina as part of the A. V. Topchiev Institute of Petrochemical Synthesis (TIPS) Russian Academy of Sciences (RAS) State Program.

\section{Notes and references}

1 R. C. Larock, Comprehensive Organic Transformations: A Guide to Functional Group Preparations, Wiley, 1999.

2 C. A. G. N. Montalbetti and V. Falque, Tetrahedron, 2005, 61, 10827-10852.

3 V. R. Pattabiraman and J. W. Bode, Nature, 2011, 480, 471.
4 R. M. Lanigan and T. D. Sheppard, Eur. J. Org. Chem., 2013, 2013, 7453-7465.

5 M. Bodanszky, in Major Methods of Peptide Bond Formation, ed. E. Gross and J. Meienhofer, Academic Press, 1979, vol. 1, pp. 105-196.

6 E. Valeur and M. Bradley, Chem. Soc. Rev., 2009, 38, 606-631.

7 R. M. de Figueiredo, J.-S. Suppo and J.-M. Campagne, Chem. Rev., 2016, 116, 12029-12122.

8 T. Krause, S. Baader, B. Erb and L. J. Gooßen, Nat. Commun., 2016, 7, 11732.

9 S. Gaspa, A. Porcheddu and L. De Luca, Org. Biomol. Chem., 2013, 11, 3803-3807.

10 J. M. Hoerter, K. M. Otte, S. H. Gellman and S. S. Stahl, J. Am. Chem. Soc., 2006, 128, 5177-5183.

11 J. M. Hoerter, K. M. Otte, S. H. Gellman, Q. Cui and S. S. Stahl, J. Am. Chem. Soc., 2008, 130, 647-654.

12 P. Acosta-Guzmán, A. Mateus-Gómez and D. GambaSánchez, Molecules, 2018, 23, 2382.

13 Y. Liu, M. Achtenhagen, R. Liu and M. Szostak, Org. Biomol. Chem., 2018, 16, 1322-1329.

14 G. Li and M. Szostak, Nat. Commun., 2018, 9, 4165.

15 L. Becerra-Figueroa, A. Ojeda-Porras and D. Gamba-Sánchez, J. Org. Chem., 2014, 79, 4544-4552.

16 K. Banert, K. M. Aitken, R. A. Aitken, M. M. K. Boysen and S. Bräse, Science of Synthesis: Houben-Weyl Methods of Molecular Transformations Vol. 41: Nitro, Nitroso, Azo, Azoxy, and Diazonium Compounds, Azides, Triazenes, and Tetrazenes, Thieme, 2014.

17 E. C. d. Lima, C. C. d. Souza, R. d. O. Soares, B. G. Vaz, M. N. Eberlin, A. G. Dias and P. R. R. Costa, J. Braz. Chem. Soc., 2011, 22, 2186-2190.

18 M. T. La and H.-K. Kim, Can. J. Chem., 2018, 96, 1135-1141. 19 S. Shi, S. P. Nolan and M. Szostak, Acc. Chem. Res., 2018, 51, 2589-2599.

20 B. Gnanaprakasam and D. Milstein, J. Am. Chem. Soc., 2011, 133, 1682-1685. 
21 T. Ohshima, Y. Hayashi, K. Agura, Y. Fujii, A. Yoshiyama and K. Mashima, Chem. Commun., 2012, 48, 5434-5436.

22 C. Han, J. P. Lee, E. Lobkovsky and J. A. Porco, J. Am. Chem. Soc., 2005, 127, 10039-10044.

23 K. E. Price, C. Larrivée-Aboussafy, B. M. Lillie, R. W. McLaughlin, J. Mustakis, K. W. Hettenbach, J. M. Hawkins and R. Vaidyanathan, Org. Lett., 2009, 11, 2003-2006.

24 Y.-S. Bao, B. Zhaorigetu, B. Agula, M. Baiyin and M. Jia, J. Org. Chem., 2014, 79, 803-808.

25 C. Sabot, K. A. Kumar, S. Meunier and C. Mioskowski, Tetrahedron Lett., 2007, 48, 3863-3866.

26 A.-T. Talvik, A. Tuulmets and E. Vaino, J. Phys. Org. Chem., 1999, 12, 747-750.

27 M. M. Heravi, Z. Kheilkordi, V. Zadsirjan, M. Heydari and M. Malmir, J. Organomet. Chem., 2018, 861, 17-104.

28 P. Ruiz-Castillo and S. L. Buchwald, Chem. Rev., 2016, 116, 12564-12649.

29 D. S. Surry and S. L. Buchwald, Chem. Sci., 2011, 2, 27-50.

30 J. Bariwal and E. Van der Eycken, Chem. Soc. Rev., 2013, 42, 9283-9303.

31 A. J. Burke and C. S. Marques, Catalytic Arylation Methods: From the Academic Lab to Industrial Processes, Wiley, 2015.
32 T. Ben Halima, J. K. Vandavasi, M. Shkoor and S. G. Newman, ACS Catal., 2017, 7, 2176-2180.

33 S. Shi and M. Szostak, Chem. Commun., 2017, 53, 1058410587.

34 A. H. Dardir, P. R. Melvin, R. M. Davis, N. Hazari and M. Mohadjer Beromi, J. Org. Chem., 2018, 83, 469-477.

35 K. Amaike, K. Muto, J. Yamaguchi and K. Itami, J. Am. Chem. Soc., 2012, 134, 13573-13576.

36 K. Muto, J. Yamaguchi, D. G. Musaev and K. Itami, Nat. Commun., 2015, 6, 7508.

37 R. Takise, K. Muto and J. Yamaguchi, Chem. Soc. Rev., 2017, 46, 5864-5888.

38 M. Tobisu and N. Chatani, Acc. Chem. Res., 2015, 48, 17171726.

39 E. J. Tollefson, L. E. Hanna and E. R. Jarvo, Acc. Chem. Res., 2015, 48, 2344-2353.

40 J. Cornella, C. Zarate and R. Martin, Chem. Soc. Rev., 2014, 43, 8081-8097.

41 B. Vigante, M. Rucins, A. Plotniece, K. Pajuste, I. Luntena, B. Cekavicus, E. Bisenieks, R. Smits, G. Duburs and A. Sobolev, Molecules, 2015, 20, 19697. 